https://helda.helsinki.fi

Job resources and work engagement among Finnish dairy farmers

Kallioniemi, Marja

2018-07-26

Kallioniemi , M , Kaseva , J , Lunner Kolstrup , C , Simola , A \& Kymäläinen , H-R 2018 , ' Job resources and work engagement among Finnish dairy farmers ', Journal of pÿAgromedicine , vol. 23 , no. 3 , pp. 249 261 . https://doi.org/10.1080/1059924X.2018.1470047

http://hdl.handle.net/10138/311256

https://doi.org/10.1080/1059924X.2018.1470047

acceptedVersion

Downloaded from Helda, University of Helsinki institutional repository.

This is an electronic reprint of the original article.

This reprint may differ from the original in pagination and typographic detail.

Please cite the original version. 
JOB RESOURCES AND WORK ENGAGEMENT AMONG FINNISH DAIRY FARMERS

This is an Accepted Manuscript of an article published by Taylor \& Francis in Journal of Agromedicine on $26^{\text {th }}$ July, 2018, available online:

http://www.tandfonline.com/10.1080/1059924X.2018.1470047.

Kallioniemi, Marja K. ${ }^{1}$, Kaseva, Janne ${ }^{2}$, Lunner Kolstrup, Christina ${ }^{3}$, Simola, Ahti ${ }^{4}$ \& Kymäläinen, Hanna-Riitta ${ }^{5}$ 2018. Job resources and work engagement among Finnish dairy farmers. Journal of Agromedicine 23(3):249-261.

DOI: $10.1080 / 1059924 X .2018 .1470047$

Institutional Affiliations:

${ }^{1}$ Bioeconomy and Environment, Natural Resources Institute Finland (Luke), Espoo, Finland

${ }^{2}$ Natural Resources and Bioproduction, Natural Resources Institute Finland (Luke), Jokioinen, Finland

${ }^{3}$ Department of Work Science, Business Economics \& Environmental Psychology (AEM), Swedish University of Agricultural Sciences (SLU), Alnarp, Sweden

${ }^{4}$ Organizational Psychology Emeritus, Finnish Institute of Occupational Health (FIOH), Jyväskylä, Finland

${ }^{5}$ The Department of Agricultural Sciences, University of Helsinki, Helsinki, Finland

Address for correspondence:

Marja K. Kallioniemi,

Research Scientist, PhD

Natural Resources Institute Finland (Luke)

Bioeconomy and environment

e-mail: marja.kallioniemi@luke.fi

phone: +358295326207

address: Luke, c/o University of Aalto,

PL 15600, FI-00076 Aalto, Finland

www.luke.fi 
Journal of Agromedicine 23(3): 249-261. DOI: 10.1080/1059924X.2018.1470047

\title{
JOB RESOURCES AND WORK ENGAGEMENT AMONG FINNISH DAIRY FARMERS
}

Authors:

Marja K. Kallioniemi, Janne Kaseva, Christina Lunner Kolstrup, Ahti Simola \& Hanna-Riitta Kymäläinen

\begin{abstract}
Objectives: The aims of this study were to examine job resources, work engagement and Finnish dairy farmers' preferences concerning methods to enhance overall well-being while working on farms.

Methods: A postal survey yielded 265 completed questionnaires from 188 dairy farms. The sample was assessed as representative of Finnish dairy farmers. Exploratory factor analysis and a linear mixed model were utilized during the data analyzing process.

Results: The variables lowering work engagement were stressors related to the workload and problems with health. Elevated work engagement was associated with the factors work with farm animals and family. The most important resource variables were "child or children", "own family", and "animal health". Female dairy farmers considered resource variables related to the family, love, and work with cattle as significantly more important than male dairy farmers. Male dairy farmers experienced higher work engagement and, concerning the dimensions, especially higher dedication and absorption than male respondents in a reference sample of workers in difference occupations. A sustainable farm economy and the possibility to have a holiday period were the most important methods to improve overall well-being on dairy farms.

Conclusion: The results indicate that the family, working with cattle, healthy farm animals, a reasonable workload, and a sustainable farm economy have the capacity to create positive impacts on well-being among dairy farmers. Well-being on farms is a part of sustainable food production.
\end{abstract}

Keywords agriculture; dairy farm; job resource; well-being; work engagement

\section{Introduction}

Dairy farmers represent an occupational group that confronts psychosocial demands, expectations, and stressors. ${ }^{1}$ Earlier psychological research has widely focused on healing damage, but the emergence of positive psychology has highlighted human strengths which have a capacity to provide fruitful means for therapeutic efforts. ${ }^{2}$ Health-improving programs should, in addition to daily health promotion, enhance job resources, because this advances engagement, commitment, and motivation in work organizations. ${ }^{3}$ Job resources enable the achievement of work goals, reduce work demands, and enhance human development. ${ }^{4-6}$ In more detail, Scaufeli and Bakker ${ }^{4}$ define job resources as physical, psychological, social, or 
organizational features that may (1) reduce job demands "at the associated physiological and psychological costs"; (2) are functional in achieving work goals; (3) enhance personal growth and development. In addition, job resources facilitate personal initiative, which promotes innovation in work places. ${ }^{7}$

Job resources can be divided into objects (e.g., a house or computer), personal characteristics (e.g., skills of human interaction, optimism), conditions (e.g., an interesting job, nature), or energies (e.g., money, physical or mental capacity). ${ }^{8}$ Applying the theory of conservation of resources regarding stress, Hobfoll ${ }^{8}$ described how humans aim to achieve and maintain different types of resources. Stress is a result of a demanding situation, where a person is in significant danger of losing resources or is unsuccessful in his or her efforts to achieve resources. In addition, the job demand-resources model (JD-R) demonstrated that the availability of resources may lead to the reduction of disengagement. ${ }^{4}$ Job resources, personal resources and work engagement have a reciprocal relationship, which may form a cycle leading towards "successful adaptation" to the work environment. 9

The mentioned work engagement is defined as "a positive, fulfilling, work-related state of mind", which has three dimensions: vigor, dedication, and absorption. ${ }^{6,10}$ A person with vigor works with high energy and mental resilience. Vigor also increases the inclination to put effort into work and adds persistence, if difficulties are confronted. Dedication indicates being highly involved in work, and is revealed by senses of significance, enthusiasm, inspiration, pride, and challenge. Absorption is described as being "concentrated and happily engrossed" in work; time passes quickly and it may be difficult to disentangle oneself from work tasks. ${ }^{6,10}$

This study focused on positive and remedial elements of work, namely job resources and work engagement, among dairy farmers in Finland. The study also provided information on the preferences of dairy farmers concerning the methods to improve overall well-being. The study sought novel background knowledge enabling intervention among this occupational group. The research questions were:

1. How do dairy farmers assess the given resource variables? How do job resources differ between female and male respondents?

2. Focusing on work engagement, (a) how much work engagement do dairy farmers experience, and (b) which variables are associated with work engagement?

3. What methods do dairy farmers recognize to improve well-being on dairy farms?

\section{Methods}

A postal survey was based on a random sample of 400 Finnish dairy farms obtained from a register of the Ministry of Agriculture and Forestry. Each selected farm received two questionnaires with a letter requesting responses from the farmer, farming couple, or the persons regularly working with cattle. The questionnaires were posted twice in 2010, and a reminder post card was sent to the sample. Finally, a total of 265 completed questionnaires 
were received from 188 dairy farms, constituting a response rate of $47 \%$. In total, 111 dairy farms returned one and 77 dairy farms returned two completed questionnaires.

The survey posed questions concerning work engagement, resource variables, and methods to enhance well-being. In addition, the survey also included questions about stress, burnout, ${ }^{11}$ animal welfare, conditions in the barn, and the animal-human relationship. Two farms were visited and the planned questions were posed during a discussion about the questionnaire. Feedback was assessed by the researcher group. Later, a revised questionnaire was sent to four dairy farmers for feedback. These farmers were identified from a discussion site of dairy farmers on the Internet, where a researcher sent a message asking for voluntary questionnaire testers.

Assessment of Resource Variables. 26 resource variables were presented in the questionnaire with the question, "Which of the following are resource variables that enable you to develop a positive attitude and cope in your everyday life?" The instruction was to assess the variables on a seven-step scale from 1 ("completely meaningless") to 7 ("very important"). The resource variables were selected based on literature references (Table 1). The 26 resource variables are listed in Figure 1, and a reduced list of 22 resource variables forming six factors identified in exploratory factor analysis (EFA) is presented in Table 1.

Assessment of Stressors. The questionnaire included a table of 18 stressors with the following instruction: "Estimate your own stressors in your current situation in life. Which issues do you experience as stressful, inconvenient or tiring?" The respondents were asked to assess each stressor on a seven-step scale from 1 ("not stressful at all") to 7 ("very stressful"). ${ }^{11}$ The stressors were selected based on literature references (Table 2). A reduced list of 12 stressors and three associated factors identified in EFA is presented in Table 2.

Work Engagement. The Utrecht Work Engagement Scale (UWES-9) was utilized to measure work engagement. ${ }^{10}$ The following are examples of the items: "At my work, I feel bursting with energy" (dimension vigor); "My job inspires me" (dimension dedication); and "I feel happy when I am working intensely" (dimension absorption). ${ }^{10}$ Each item was assessed with the scale: $0=$ never; $1=$ a few times a year or less; $2=$ once a month or less; $3=$ a few times a month; 4 = once a week; 5 = a few times a week; and $6=$ every day.

Comparison with Reference Sample. The Finnish Institute of Occupational Health (FIOH) provides a reference sample $(\mathrm{N}=16,335)^{12}$ in order to enable the interpretation and assessment of the results of the UWES- $9^{10}$. The reference sample was gathered from 2001 to 2007 and includes respondents in different occupations. The sample is not representative of working Finnish citizens, but it has been assessed as wide and multifaceted enough to be used in psychometric comparisons. ${ }^{12}$ Because this study and the reference sample were not gathered during the same time period, the results of this comparison must be interpreted with caution. 
Child or children $(105,135,240)$

Own family $(112,141,253)$

Love $(108,140,248)$

Animal health $(112,146,258)$

Own spouse or companion $(103,138,241)$

Substitute farm work service (a) $(112,144,256)$

Sufficient income $(112,144,256)$

Living environment $(114,145,259)$

Freedom in work $(112,146,258)$

Work near nature $(111,146,257)$

Success of farm enterprise $(112,145,257)$

Friends $(111,145,256)$

Work atmosphere $(112,143,255)$

Diversified work $(111,144,255)$

Follow-up of animal behavior $(111,146,257)$

Sufficient free time $(113,144,257)$

The affection shown by farm animals $(109,145,254)$

Working with farm animals $(114,146,260)$

Farming lifestyle $(107,144,251)$

Esteem of work $(109,143,252)$

Own hobby $(109,144,253)$

Relatives $(111,145,256)$

Neighbors $(111,146,257)$

Support from other farmers $(107,141,248)$

Religion $(110,144,254)$

Position of responsibility $(110,141,251)$
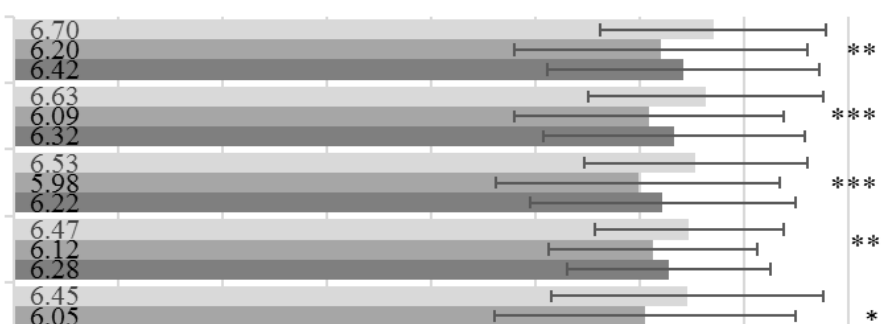

(5.

\section{(5.0.}

\section{$\frac{6}{6}$}

(5.9.

) 5.96
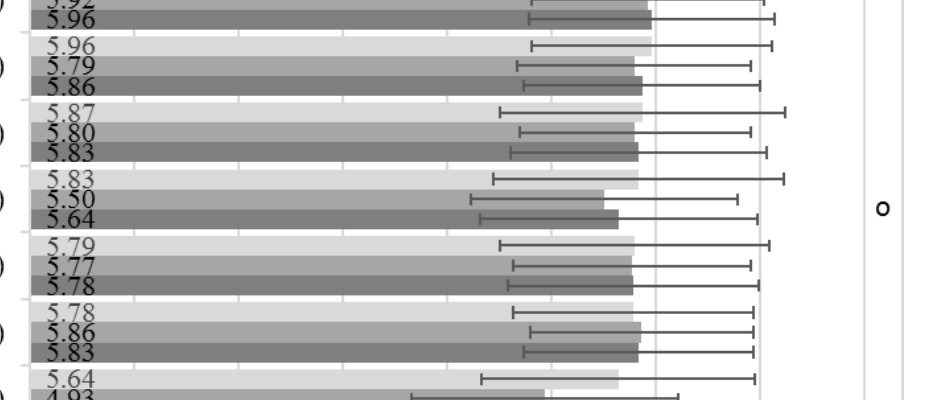

\section{) 4.}

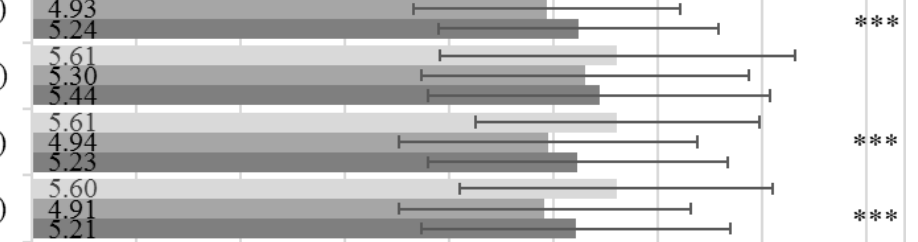

\section{(5)}

\section{(5)}

\section{)}
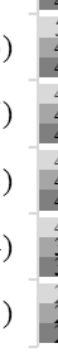
between females and males are indicated with ${ }^{* * *} P<.001,{ }^{* *} P<.01,{ }^{*} P<.05$ or ${ }^{\circ} P<.10$. (a) Complete form of the resource variable: "Substitute farm work service or substitute during holiday".

Methods to Enhance Well-being. The respondents were asked to assess a list of methods to enhance animal welfare and human well-being on dairy farms, and to rank the three most relevant methods with the numbers 1,2, and 3. The most important method was given three points, the second two points, and the third one point, respectively. Finally, the points for each method were summarized. The measure enabled determination of the preferences of the respondents and their opinions regarding the usefulness of the methods. Information on effective intervention options is needed, because of the challenging economic situation.

\section{Data analysis}

The strategy and three parts of the data analysis are presented in Figure 2. Part 1 compares the importance of resource variables by gender. The familywise error rate was controlled with conservative Bonferroni correction. There were 26 questions, so familywise error rate had to be controlled. Significance level $\alpha=.05$ was used but each unadjusted $P$-value was multiplied by 26 . For example, unadjusted $P=.001$ was interpreted as Bonferroni's $P=.026 .^{13}$ The relationships of background variables with job resources and work engagement were examined using correlation analysis, analysis of variance, and crosstabulation. The relationships of 14 background variables were examined with job resources and work engagement; these variables included demographic variables such as gender, age, marital status, education and work experience; variables related to farms such as the amount of cows and young cattle, cattle barn type, farm type, involvement in the milk recording system and in the Centralized health care register for Finnish cattle herds (Naseva), the amount of milk production, the amount of workers and the economic situation. Welch's ANOVA test was used when the assumption of homogeneity of variances was not met. Exploratory factor analysis (EFA) was used to identify the number of latent constructs and the possible underlying factor structure of stressors and job resources. EFA with the maximum likelihood (ML) extraction was separately applied to job resources and stressors, and the scree test, the proportion of variation explained, and the interpretability of factors were used as criteria. The original information concerning 26 resource variables and 18 stressors was reduced with EFA to nine factors (Tables 1 and 2). Unsuitable stressors (7) and resource variables (4) were eliminated during EFA based on low communalities $(<0.3)$. After rotation, six factors based on resource variables were established.

The validity and reliability of the stressors and resource variables were tested. The sampling adequacy of both, tested with the Kaiser-Melkin-Olkin (KMO) measure, was "meritorious" $(\mathrm{KMO}>0.8)$. The Bartlett's spherity test was also significant $(P<.0001)$ in both cases. The internal consistency of the stressors and resources was measured using Cronbach's alpha. ${ }^{14}$ The standardized alphas were good $(\alpha=.86)$ and excellent $(\alpha=.92)$, respectively. 
Table 1. The results of the Promax-rotated exploratory factor analysis: resource variables, communality of variables, established factors, and loadings. The eigenvalues of the factors, Cronbach's a values, the Squared Multiple Correlation (SMC) values, and correlations between factors are presented in the bottom rows.

The letters indicate literature references, the reference number is in parentheses: ${ }^{a}(8) ;{ }^{b}(25) ;{ }^{c}(27) ;{ }^{d}(53) ;{ }^{e}(54) ;{ }^{f}(21) ;{ }^{g}(55) ;{ }^{h}(53) ;{ }^{i}(26) ;{ }^{j}(38) ;{ }^{k}(37) ;{ }^{\prime}(56)$. The most interpretable factor loadings are in bold.

\begin{tabular}{|c|c|c|c|c|c|c|c|}
\hline \multirow[b]{2}{*}{ Resource variable } & \multirow[b]{2}{*}{$\begin{array}{l}\text { Communality } \\
\text { of variable }\end{array}$} & \multicolumn{6}{|c|}{ Factors and loadings } \\
\hline & & $\begin{array}{l}\text { Family } \\
\text { (F1) }\end{array}$ & $\begin{array}{l}\text { Work and living } \\
\text { environment } \\
\text { (F2) }\end{array}$ & $\begin{array}{l}\text { Social } \\
\text { relationships } \\
\text { (F3) }\end{array}$ & $\begin{array}{l}\text { Work with } \\
\text { farm animals } \\
\text { (F4) }\end{array}$ & $\begin{array}{c}\text { Success of the } \\
\text { farm enterprise } \\
\text { (F5) }\end{array}$ & $\begin{array}{c}\text { Free } \\
\text { time }(F 6)\end{array}$ \\
\hline Own family ${ }^{a-e}$ & 0.869 & 0.971 & -0.076 & 0.000 & 0.084 & -0.033 & -0.046 \\
\hline Child or children $^{\mathrm{a}}$ & 0.732 & 0.925 & -0.010 & -0.034 & -0.049 & -0.054 & -0.053 \\
\hline Own spouse or companion ${ }^{a}$ & 0.744 & 0.784 & 0.042 & -0.001 & -0.029 & 0.089 & 0.053 \\
\hline Love $^{\mathrm{a}}$ & 0.630 & 0.591 & 0.039 & 0.193 & 0.022 & 0.042 & 0.081 \\
\hline Work near nature $e^{c, d}$ & 0.536 & -0.112 & 0.738 & -0.034 & 0.100 & -0.017 & -0.026 \\
\hline Freedom in work ${ }^{c}$ & 0.494 & -0.011 & 0.690 & -0.055 & 0.020 & 0.079 & -0.024 \\
\hline Diversified work $^{d}$ & 0.437 & -0.093 & 0.629 & 0.007 & 0.051 & 0.018 & 0.053 \\
\hline Living environment ${ }^{\mathrm{e}, \mathrm{i}}$ & 0.400 & 0.150 & 0.579 & 0.129 & -0.096 & -0.115 & 0.013 \\
\hline Work atmosphere & 0.508 & 0.174 & 0.557 & -0.029 & 0.032 & 0.043 & 0.082 \\
\hline Farming lifestyle ${ }^{c}$ & 0.447 & -0.007 & 0.513 & 0.229 & 0.042 & 0.084 & -0.082 \\
\hline Neighbors ${ }^{i}$ & 0.672 & -0.021 & 0.154 & 0.851 & -0.059 & -0.071 & -0.105 \\
\hline Relatives $^{c}$ & 0.592 & 0.066 & -0.135 & 0.733 & 0.093 & 0.070 & -0.012 \\
\hline Support from other farmers ${ }^{\mathrm{f}-\mathrm{h}}$ & 0.448 & -0.050 & 0.006 & 0.619 & 0.064 & 0.025 & 0.061 \\
\hline Friends $s^{\mathrm{a}, \mathrm{b}, \mathrm{h}}$ & 0.637 & 0.096 & 0.030 & 0.604 & -0.093 & -0.022 & 0.255 \\
\hline $\begin{array}{l}\text { The affection shown by farm } \\
\text { animals }^{\mathrm{c}}\end{array}$ & 0.892 & -0.105 & -0.052 & 0.128 & 0.960 & -0.009 & -0.070 \\
\hline Working with farm animals ${ }^{c}$ & 0.663 & -0.001 & 0.022 & 0.056 & 0.783 & -0.048 & 0.060 \\
\hline
\end{tabular}




\begin{tabular}{|c|c|c|c|c|c|c|c|}
\hline Follow-up of animal behavior ${ }^{\mathrm{C}}$ & 0.677 & 0.091 & 0.135 & -0.127 & 0.742 & 0.048 & -0.013 \\
\hline Animal health ${ }^{c}$ & 0.420 & 0.205 & 0.175 & -0.092 & 0.422 & 0.045 & 0.079 \\
\hline $\begin{array}{l}\text { Success of the farm } \\
\text { enterprise }{ }^{\mathrm{a}, \mathrm{c}, \mathrm{e}}\end{array}$ & 0.896 & -0.023 & -0.014 & 0.050 & -0.030 & 0.995 & -0.087 \\
\hline Sufficient income $e^{\mathrm{a}, \mathrm{c}, \mathrm{e}}$ & 0.702 & 0.018 & 0.089 & -0.076 & 0.026 & 0.740 & 0.114 \\
\hline Esteem of the work ${ }^{\mathrm{a}, \mathrm{k}}$ & 0.445 & 0.058 & 0.012 & 0.297 & 0.075 & 0.335 & 0.101 \\
\hline Sufficient free time ${ }^{a}$ & 0.759 & -0.025 & -0.053 & 0.047 & -0.032 & 0.142 & 0.810 \\
\hline $\begin{array}{l}\text { Substitute farm work service } \\
\text { or substitute during a holiday }\end{array}$ & 0.592 & 0.019 & 0.023 & -0.017 & -0.053 & -0.028 & 0.783 \\
\hline Own hobby ${ }^{\mathrm{d}, \mathrm{h}}$ & 0.392 & 0.002 & 0.073 & 0.084 & 0.221 & -0.127 & 0.506 \\
\hline \multicolumn{2}{|c|}{ Eigenvalues (based on PCA) } & 8.53 & 2.64 & 1.66 & 1.46 & 1.37 & 1.05 \\
\hline \multicolumn{2}{|c|}{ Cronbach's $\alpha$} & 0.91 & 0.82 & 0.83 & 0.88 & 0.87 & 0.76 \\
\hline \multicolumn{2}{|c|}{ Squared Multiple Correlation } & 0.94 & 0.85 & 0.87 & 0.93 & 0.92 & 0.86 \\
\hline \multicolumn{2}{|c|}{ Correlations among factors } & $\begin{array}{l}\text { F1-F2: } \\
0.52 ; \mathrm{F} 2 \\
\text { F6: } 0.23\end{array}$ & $\begin{array}{l}\mathrm{F} 3: 0.4 \\
5 ; \mathrm{F} 2-\mathrm{F} \\
0.51\end{array}$ & $\begin{aligned} 0.24 ; F \\
3-F 4: 0\end{aligned}$ & $\begin{array}{l}\text { 37; F1- } \\
\text { F5: } 0.3\end{array}$ & $\begin{array}{l}2-F 3: 0 \\
52 ; \mathrm{F} 4\end{array}$ & $\begin{array}{l}\text { F4: } \\
8 ; \mathrm{F} 4-\end{array}$ \\
\hline
\end{tabular}


Table 2. The results of the exploratory factor analysis: stressors, communality of variables, established factors, and loadings. The eigenvalues of the factors, Cronbach's $\alpha$ values, the squared multiple correlation (SMC) values, and correlations between factors are presented in the bottom rows.

The letters indicate literature references, the reference number is in parentheses: ${ }^{\mathrm{a}}(57) ;{ }^{\mathrm{b}}(58) ;{ }^{\mathrm{c}}(59) ;{ }^{\mathrm{d}}(60) ;{ }^{\mathrm{e}}(61) ;{ }^{\mathrm{f}}(25) ;{ }^{\mathrm{g}}(28) ;{ }^{\mathrm{h}}(62)$.

The most interpretable factor loadings are in bold.

\begin{tabular}{|c|c|c|c|c|}
\hline \multirow[b]{2}{*}{ Stressor } & \multirow{2}{*}{$\begin{array}{l}\text { Communality } \\
\text { of variable }\end{array}$} & \multicolumn{3}{|c|}{ Factors and loadings } \\
\hline & & $\begin{array}{l}\text { Governance and } \\
\text { responsibilities }\end{array}$ & $\begin{array}{l}\text { Workload and } \\
\text { own health }\end{array}$ & Loneliness \\
\hline Agricultural policy of the $E U^{a-c}$ & 0.753 & 0.915 & -0.094 & -0.007 \\
\hline The treatment of farmers in society and the media ${ }^{b-d}$ & 0.640 & 0.825 & -0.075 & 0.063 \\
\hline Administration of the farm ${ }^{c-e}$ & 0.508 & 0.678 & 0.082 & -0.086 \\
\hline The future of the agricultural sector ${ }^{\mathrm{b}, \mathrm{d}}$ & 0.482 & 0.665 & 0.051 & 0.007 \\
\hline Complex responsibilities and duties $\mathrm{s}^{\mathrm{e}-\mathrm{g}}$ & 0.475 & 0.545 & 0.223 & -0.002 \\
\hline Lack of possibility to predict work situations $s^{a, b}$ & 0.460 & 0.522 & 0.211 & 0.066 \\
\hline Physical load of work ${ }^{\mathrm{b}, \mathrm{c}, \mathrm{g}}$ & 0.628 & 0.109 & 0.748 & -0.062 \\
\hline Amount of work ${ }^{\mathrm{b}, \mathrm{c}, \mathrm{g}}$ & 0.500 & -0.015 & 0.726 & -0.035 \\
\hline Own health ${ }^{b-d}$ & 0.345 & 0.037 & 0.552 & 0.039 \\
\hline Loss of sleep ${ }^{h}$ & 0.310 & 0.033 & 0.387 & 0.269 \\
\hline Loneliness $^{\mathrm{a}-\mathrm{d}}$ & 1.000 & -0.030 & 0.055 & 0.986 \\
\hline Lack of companion $^{\mathrm{a}}$ & 0.348 & 0.039 & -0.059 & 0.601 \\
\hline Eigenvalues (based on PCA) & & 4.756 & 1.734 & 1.192 \\
\hline Cronbach's $\alpha$ & & 0.875 & 0.732 & 0.739 \\
\hline Squared Multiple Correlation & & 0.895 & 0.802 & 0.999 \\
\hline Correlations among factors & & \multicolumn{3}{|c|}{ F1-F2: 0.53; F1-F3: 0.18; F2-F3: 0.33} \\
\hline
\end{tabular}


Because of the moderately correlated factors, non-orthogonal (oblique) promax rotation was used to achieve a more meaningful and interpretable solution. The inter-factor correlations are presented in Tables 1 and 2. The correlations ranged between .18 and .53. However, both rotation methods (orthogonal and oblique) led to very similar structures. When there were few missing values per respondent, multiple imputation for missing data was used to obtain the factor scores for all respondents. The SAS procedure MI, which uses the multivariate normal approach via the Markov chain Monte Carlo method, was used for multiple imputations. ${ }^{15}$ The effects of the imputations on the factor structure were examined and found negligible. Concerning the resource variables and stressors, the amount of imputed variables was lower than $2 \%$. Factor scores, calculated by a regression method, were used as continuous predictor variables in further analysis. The internal consistencies of the factors, measured using Cronbach's alpha, ranged from acceptable to excellent (.73-.91).

A linear mixed model was applied to model work engagement. Correlated answers within a farm, having compound symmetry covariance structure, were analyzed as random effect of farm. The analyses included both background variables and factor score variables. The main effects of the chosen categorical variables and continuous variables (including factor score variables) were tested. The linear relationships between the continuous variables and work engagement were also checked with scatter plots. Secondly, all potentially interesting twoway interactions were included in the model and found to be non-significant. Selection of interactions was a reasonable step in the data analysis because of the large number of possible interactions, which were not all relevant or interesting. Thus, three factor score variables and two background variables were included in the final model. All factor score variables were standardized and other continuous variables were centered to make interpretation more logical and meaningful. The appropriateness of the models was assessed by analysis of residuals. The models were fitted by using the residual maximum likelihood (REML) estimation method and the degrees of freedom were calculated using the Kenward-Roger method. Pseudo $R$-squared values and information criteria (Akaike and Bayesian) were used in testing the goodness of fit. ${ }^{16,17}$

Comparison of work engagement with the reference sample was conducted using the $t$-test for two independent samples. Three dimensions of work engagement were also separately compared. In the results section, information is provided on differences in the means, standard errors and $P$-values. Statistical analyses were performed with the software package SAS Enterprise Guide 6.1. (SAS Institute Inc., Cary, NC, USA). The function 'r.squaredGLMM' from the R package 'MuMIn' through version 3.4.1 was used in the calculation of pseudo $R$-squared values.$^{18}$ 


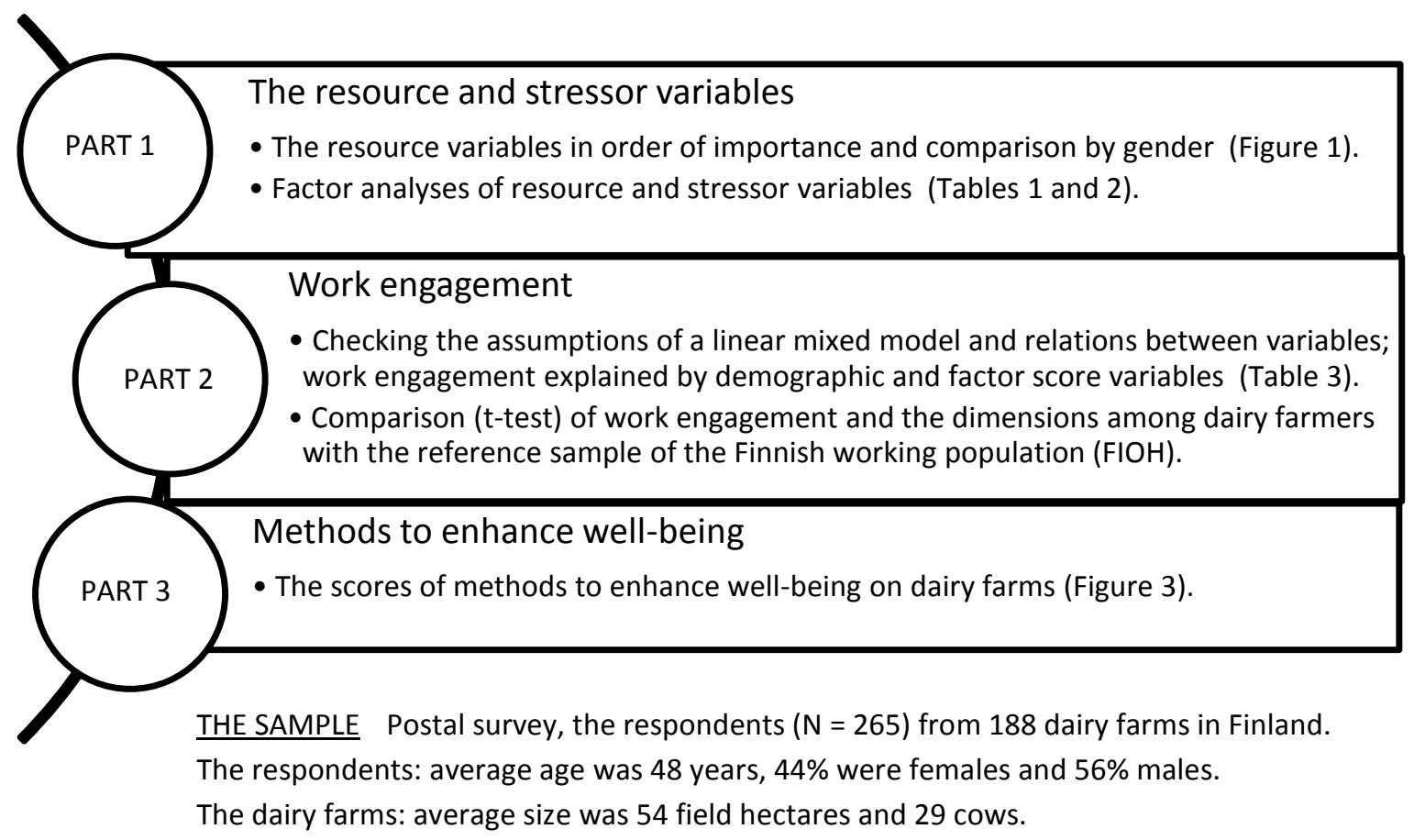

Figure 2. The strategy and three parts of the data analysis.

\section{Results}

Participants. The average age among the respondents (47.8 years) was slightly lower than among all Finnish farmers (50.6 years) in 2010. ${ }^{19}$ The proportions of female and male respondents were $44 \%$ and $56 \%$, respectively. The average size of the dairy farms was larger (54.0 field hectares, 29.0 cows) than on average in Finland (36.7 hectares, 24.3 cows). ${ }^{19}$ Concerning the cattle barn type, the proportion of tie-stall barns was nearly the same (78\%) as among the farms that took part in the Finnish milk production record system $(74 \%) .{ }^{20}$

Assessment of Resource Variables (research question 1). Figure 1 includes the assessment of resource variables among female, male, and all respondents. The most important resource variables among all respondents were "child or children" (6.42 \pm 1.30$)$, "own family" (6.32 \pm $1.25)$, and "animal health" $(6.28 \pm 0.97)$. Variables assessed as the most meaningless were "position of responsibility" (2.60 \pm 1.63$)$, "religion" $(3.84 \pm 1.95)$, and "support from other farmers" (4.20 \pm 1.67$)$.

The average score for all resource variables was higher (5.63) among female than male respondents (5.31). Female farmers gave significantly higher scores $(P<.001)$ for the following resource variables: "family", "love", "follow-up of animal behavior", "the affection shown by farm animals", and "working with farm animals". Significantly higher scores $(P<.01)$ also were observed for the resource variables "child or children", "animal health", "own hobby", and "religion". 
Work Engagement and Associated Variables (research question 2). Concerning the total score for work engagement, the following measures were determined: the mean $(4.37 \pm 1.28)$, range (0-6), and Cronbach's alpha (.92). The relationships between work engagement and dairy farmer demographics were analyzed with one-way ANOVA. The only statistically significant relationship for work engagement was observed with the economic situation of the farm $\left(\mathrm{F}_{1,246}=3.779, P=.024\right)$.

The linear mixed model explained $32 \%$ of the marginal and $54 \%$ of the conditional variance in the reported work engagement (Table 3). The first describes the proportion of variance explained by fixed effects and the latter the proportion of variance explained by both fixed and random effects, respectively. A factor that associated with a lowering of work engagement was workload and own health, while an increasing association was found with the factor work with farm animals. In addition, work engagement had a significant association with the factor family, and a larger number of cows also had an association with work engagement. Because the factor score variables were standardized and the number of cows was centered, the intercept term describes the predicted score for work engagement (4.553) when the other variables are held constant (average values). A one-standard-deviation increase in the factor score variables workload and own health, family, and work with farm animals respectively led to a decrease of 0.474 and an increase of 0.246 and 0.373 in the predicted score for work engagement when the other variables were held constant. Farms having 10 cows more than on average were expected to have an increase of 0.058 in the predicted score for work engagement when the other variables were held constant. The expected mean difference in work engagement was approximately 0.28 points higher among men than women, holding the other predictor variables constant. The factor workload and own health had the strongest and the number of cows the smallest relationship with work engagement.

Comparison with the Reference Sample. The average measurements of work engagement did not significantly differ $(0.109 \pm 0.081, P=.177)$ between this study and the reference sample of FIOH $(\mathrm{N}=16,335)$, but concerning the dimensions, dairy farmers reported significantly more dedication $(0.243 \pm 0.084, P=.004)$ and absorption $(0.278 \pm 0.090, P=.002)$. No statistically significant differences were observed concerning the responses of females $(0.001$ $\pm 0.136, P=.994)$. Male dairy farmers experienced significantly more work engagement $(0.327 \pm 0.098, P=.001)$, and concerning the dimensions, more dedication $(0.411 \pm 0.104, P$ $<.001)$, and absorption $(0.442 \pm 0.115, P<.001)$ compared to males of the reference sample.

Methods to Enhance Well-being on Dairy Farms (research question 3). Two methods (Figure 3) were more pronounced than the others: "Securing the profitability of the sector" and "Improving the substitute assistance service". Conversely, "Increasing the control of farms" and "Increasing transparency and farm-specific information on animal welfare" contributed little to enhancing well-being. 
Table 3. The factors or variables associated with work engagement based on a linear mixed model. All the factors are standardized and the number of cows is centered.

The factors were established from the resource variables or stressors presented in Tables 1 and 2.

\begin{tabular}{|c|c|c|c|c|c|c|c|}
\hline Factors or variable & Estimate & $\begin{array}{c}\text { Standard } \\
\text { Error }\end{array}$ & $d f$ & t-value & $P$-value & $\begin{array}{r}95 \% \text { Co } \\
\text { Lir }\end{array}$ & $\begin{array}{l}\text { fidence } \\
\text { its }\end{array}$ \\
\hline Intercept & 4.432 & 0.072 & 161 & 61.97 & $<.0001$ & 4.291 & 4.573 \\
\hline $\begin{array}{l}\text { Family (factor, } \\
\text { resource } \\
\text { variables) }\end{array}$ & 0.216 & 0.069 & 233 & 3.10 & 0.003 & 0.079 & 0.352 \\
\hline $\begin{array}{l}\text { Work with farm } \\
\text { animals (factor, } \\
\text { resource } \\
\text { variables) }\end{array}$ & 0.334 & 0.069 & 238 & 4.83 & $<.0001$ & 0.198 & 0.471 \\
\hline $\begin{array}{l}\text { Workload and own } \\
\text { health (factor, } \\
\text { stressors) }\end{array}$ & -0.476 & 0.071 & 240 & -6.73 & $<.0001$ & -0.616 & -0.337 \\
\hline Number of cows & 0.005 & 0.003 & 200 & 1.81 & 0.075 & 0.000 & 0.011 \\
\hline
\end{tabular}

Securing the profitability of the sector

Improving the substitute assistance service

Improving the rehabilitation possibilities of farmers

Improving occupational health care

Improving farmer extension services and education possibilities (a)

Establishing a service whereby voluntary persons may assist a tired farmer on the farm

Increasing transparency and farm-specific information on animal welfare

I am not able or I do not want to answer

Increasing the control of farms

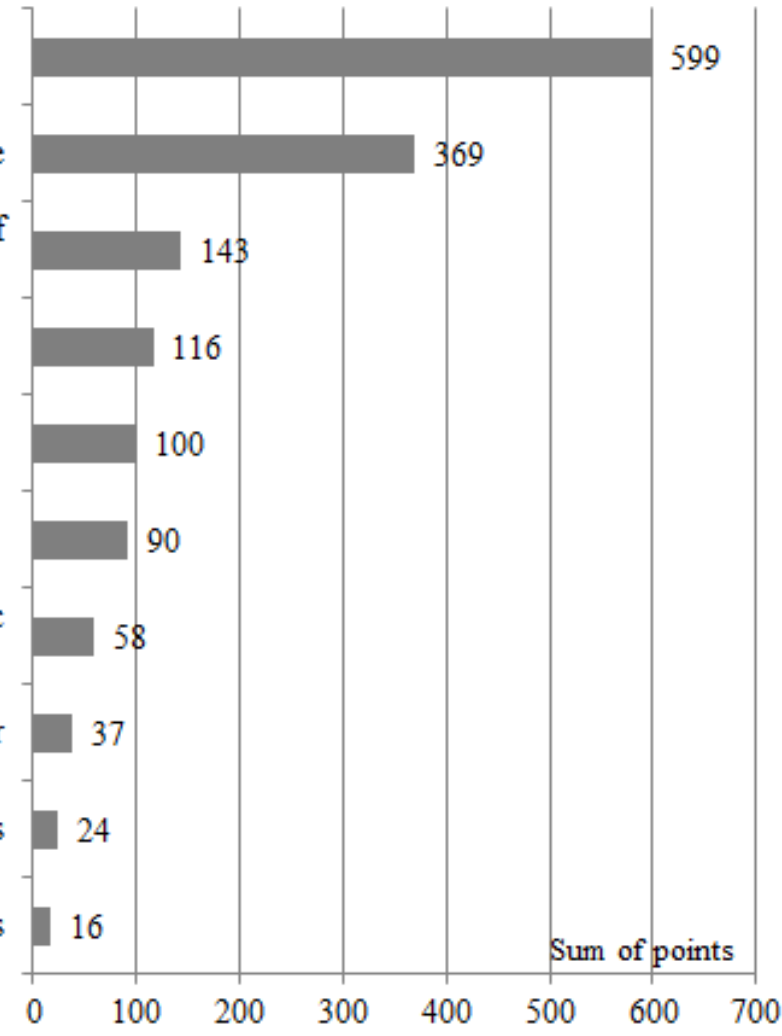

Figure 3. Methods for enhancing well-being on Finnish dairy farms presented as sum scores. The respondents were asked to assess a list of methods to enhance animal welfare and human wellbeing on dairy farms. The three most relevant methods were ranked with the numbers 1,2 , and 3 ; the most important method was given three points, the second two points, and the third one point, respectively. Finally, the points for each item were summed.

(a) For example, how to improve coping. 


\section{Discussion}

The family, close social relationships and animal health were the most important resource variables among dairy farmers. Moreover, resource variables related to the family were associated with work engagement. The methods to balance straining circumstances include enhancing and utilizing one's own resources, adjusting one's viewpoint of the situation, or simply changing the straining elements. The possibilities of individuals to apply coping methods are most effective in relation to close social relationships. ${ }^{17}$ On the other hand, problems with social relationships also may elevate strain and demands. ${ }^{21,22}$

Social relationships were among both the most important (family) and the most meaningless resource variables ("support from other farmers", "neighbors", and "relatives") among dairy farmers. Despite the rapid restructuring during recent years, Finnish agriculture is mainly based on family farming, as most farms (87\% in 2014) are owned by private persons. ${ }^{23}$ The role of the farm and the farmer encompasses both private and professional parts of life, which are mixed and difficult to separate from each other: the farm is a working place as well as a home, the spouse is also a work colleague, and children may be considered as extra helping hands or perhaps as potential farm successors. ${ }^{24}$ The family, in particular, is assessed as able to understand the demands, the values, and the circumstances of life on a farm. ${ }^{25-28}$ Because of the reported workload on dairy farms, ${ }^{29}$ the most important resource variables were perhaps those that were readily available. Social interactions outside the farm or free-time activities were among the meaningless variables, probably because many dairy farmers do not have access to or available time for these resource options.

The crucial role of the family should be recognized as a basic element in intervention efforts, for example by providing tools to maintain and strengthen the social relationships between family members. Von Schlippe and Frank ${ }^{30}$ presented a theory of social systems in family enterprises and formed three linked arenas of communication: family, entrepreneurship, and ownership. Family communication focuses on relationships, entrepreneurship communication focuses on decisions, and ownership focuses on "legally secured" communication.

Disassociation of the social interaction related to these arenas may have the potential to improve the relationships and to avoid conflicts, as the focus of interaction in each of the arenas has a specific meaning and logic. ${ }^{30}$

A good state of animal health provides concrete positive feedback for dairy farmers and improves the possibilities for free time, relaxing, and coping. In this study, "animal health" was an important resource variable, and the factor work with farm animals was associated with work engagement. The resource variables related to the family, love, and work with farm animals scored significantly higher among female than male dairy farmers. Everyday tasks of female dairy farmers often include taking care of animal welfare ${ }^{31}$ and carrying out housework. ${ }^{32}$ The intervention efforts should not ignore the approach of gender in agriculture. $^{33}$ 
According to a comparison with the reference sample of the FIOH $(\mathrm{N}=16,335),{ }^{12}$ dairy farmers reported more dedication and absorption related to dimensions of work engagement. Male dairy farmers experienced significantly more work engagement and especially more dedication and absorption than the male respondents in the reference sample. Farms are usually inherited or bought from the parents by their children and farm work often represents a continuum from earlier generations. According to patrilineal inheritance and existing habits, the farm successor is in most cases male and the male farmer is more often the representative of the farm to stakeholders outside the farm. ${ }^{33,34}$ These elements may increase work engagement among male dairy farmers. Historically, female farmers have not been considered as part of the economic sphere on farms. ${ }^{35}$ At present, the authorities define one primary farmer per farm in Finland, ${ }^{36}$ regardless of whether a spouse also works full-time on the farm. The position of the spouse is officially that of a family member.

Concurrently with the experience of work engagement, dairy farmers as a group was classified as having slight burnout symptoms. ${ }^{11}$ According to Hakanen ${ }^{37}$, work engagement and burnout are not opposite characteristics of well-being. Furthermore, high work commitment may form a path towards burnout. ${ }^{38}$ As an example, a highly motivated person may increase the length of the working days and accept a considerable number of work challenges that increase the demands of work. If the positive elements of work and life (such as resources) are not able to compensate the situation, symptoms of burnout may gradually increase. Kinnunen and Hätinen ${ }^{39}$ considered that workers may be prone to burnout if they have high work motivation combined with a belief that work gives them meaning in life.

The variables lowering work engagement were the stressors "physical load of work", "amount of work", and "own health", which formed the factor workload and own health. Dairy farmers possibly try to compensate for declining profitability by increasing their own workload. This poses a danger to the quality of life among farm families, as the possibilities for free time and recovery are limited. ${ }^{40}$ According to a consensus, long work hours increase the risk of sleep problems, fatigue and some serious illnesses like cancers and cardiovascular disease. $^{21}$

Higher work engagement was associated with maintaining larger numbers of cows. Due to the restructuring of agriculture, the average herd size on farms has rapidly increased, ${ }^{23}$ and new cattle barns with advanced technology (e.g., milking and feeding robots) have been constructed. The modern working environment may increase the likelihood of "a positive, fulfilling, work-related state of mind". ${ }^{6}$ However, evidence in the literature is lacking.

The economic situation of the farm had a statistically significant relationship with work engagement. In addition, dairy farmers emphasized the importance of a sustainable farm economy (the item "securing the profitability of the sector") and the possibility to have a vacation (the item "improving the substitute assistance service") in creating prerequisites for their well-being. Pearlin and Schooler ${ }^{42}$ described the economic achievements providing 
access to effective coping methods. In case of Finland, the northern climatic conditions and the production structure increase the costs of agriculture. ${ }^{42}$ Following European Union (EU) membership in 1995, the production costs have increased by nearly $60 \%$, but producer prices have only increased by $20 \% .{ }^{43}$ The average milk producer price in the EU declined by $18 \%$ during 2014, mainly due to the ban on imports to the Russian market. ${ }^{44}$ Despite increasing farm sizes, the entrepreneurial income from farming has been falling. ${ }^{45}$ A danger is a development where the negative impacts compound each other, such as a high workload, ${ }^{29}$ declining profitability, ${ }^{45}$ limited free time, shrinking social networks ${ }^{28}$ uncertainty, ${ }^{46}$ and morbidity ${ }^{47}$. According to the same postal survey among dairy farmers ${ }^{11}$, the most common stressors were external, such as "agricultural policy of the EU", "the treatment of farmers in society and the media", and "the future of the agricultural sector". On the other hand, literature reference emphasizes the adaptability of family farms in the course of time and in different forms of societies. ${ }^{48}$ Overall, small enterprises have been assessed as having the potential to survive amidst rapid changes in the global world. ${ }^{49}$ Human capacity is a crucial, fundamental element in the continuance of the farm enterprise.

The limitations of this study were that it was based on self-assessments and had a crosssectional design. This limits the possibilities for examining causality. ${ }^{50,51}$ In addition, respondents with ill health or having a low level of well-being might not have responded to the survey. ${ }^{52}$ However, the study was based on a representative sample of Finnish dairy farmers, which supports the generalization of the findings. Furthermore, the study provided new information on work engagement, which has not previously been examined among farmers.

\section{Conclusion}

Resource variables related to the family and animal health were the most important among the surveyed Finnish dairy farmers. The resource variables related to the family, love, and work with farm animals scored higher among female than among male respondents. Male dairy farmers experienced more work engagement and especially more dedication and absorption than male respondents in the reference sample of workers in different occupations. A high workload and problems with one's health were important variables lowering work engagement. Resource variables related to work with farm animals and family were also associated with work engagement. In addition, a positive economic situation was associated with work engagement, and the profitability of the sector also appeared as the most important method to improve overall well-being on a dairy farm. Dairy farmers emphasized also the possibility to have a vacation in creating prerequisites for well-being.

A positive environment with interaction with one's family, work with healthy farm animals, a reasonable workload, and the profitability of production were the most important issues identified as supporting well-being among dairy farmers. Stakeholders and health promotion programs should recognize these elements and support skills to enhance them. The aim should not only be to prevent ill health and problems related to well-being. Rather, by 
enhancing these positive elements, adverse outcomes could be prevented before negative consequences emerge. Discussion and means for promoting good family relationships and for limiting the workload are needed. As societal decisions are associated with the profitability and workload in farming, it is important to highlight their impact on well-being among dairy farmers. Food supply creates general well-being and security in societies. Well-being on farms is an issue connected to animal welfare and part of sustainable food production.

\section{Acknowledgements}

We warmly thank Deborah B. Reed, Distinguished Service Professor and Good Samaritan Endowed Chair, for valuable comments concerning our manuscript. We are grateful to the dairy farmers who responded to the postal survey. We also thank the whole research group for their cooperation and we appreciate the work of the steering group during the research project.

\section{Disclosure statement}

We have no conflicts of interest to disclose.

\section{Funding}

The research project "Improved well-being of dairy farmers as a means of enhancing livestock welfare" was funded by the Ministry of Agriculture and Forestry (Makera), the Farmers' Social Insurance Institution (Mela), and MTT Agrifood Research Finland.

\section{References}

1. Lunner Kolstrup C, Kallioniemi M, Lundqvist P, Kymäläinen H-R, Stallones L, Brumby S. International perspectives on psychosocial working conditions, mental health, and stress of dairy farm operators. J Agromedicine. 2013;18(3):244-255. doi:10.1080/1059924X.2013.796903

2. Seligman MEP. Positive psychology, positive prevention, and positive therapy. In: Snyder CR, Lopez SJ, eds. Handbook of Positive Psychology. Cary, UK: Oxford University Press; 2005:3-9.

3. Hakanen JJ, Scaufeli WB, Ahola K. The job demands-resources model: a three-year cross-lagged study of burnout, depression, commitment, and work engagement. Work Stress. 2008;22(3):223-241. doi:10.1080/02678370802379432

4. Demerouti E, Bakker AB, Nachreiner F, Schaufeli WB. The job demands - resources model of burnout. J Appl Psychol. 2001;86(3):499-512. doi:10.1037/0021-9010.86.3.499

5. Schaufeli WB, Bakker AB. Job demands, job resources, and their relationship with burnout and engagement: a multi-sample study. J Organ Behav. 2004;25(3):293-315. doi:10.1002/job.248

6. Bakker AB, Hakanen JJ, Demerouti E, Xanthopoulou D. Job resources boost work engagement, particularly when job demands are high. J Educ Psychol. 2007;99(2):274- 
284. doi: 10.1037/0022-0663.99.2.274

7. Hakanen J, Perhoniemi R, Toppinen-Tanner S. Positive gain spirals at work: from job resources to work engagement, personal initiative and work-unit innovativeness. $J$ Vocat Behav. 2008;73(1):78-91. doi:10.1016/j.jvb.2008.01.003

8. Hobfoll SE. The influence of culture, community, and the nested-self in the stress process: advancing conservation of resources theory. Appl Psychol. 2001;50(3):337-421. doi:10.1111/1464-0597.00062

9. Xanthopoulou D, Bakker AB, Demerouti E, Schaufeli WB. Reciprocal relationships between job resources, personal resources, and work engagement. J Vocat Behav. 2009;74(3):235-244. doi: 10.1016/j.jvb.2008.11.00

10. Schaufeli W, Bakker A. UWES Utrecht Work Engagement Scale. Preliminary Manual [version 1, November 2003]. Utrecht, Netherlands: Utrecht University; 2003.

11. Kallioniemi MK, Simola A, Kaseva J, Kymäläinen H-R. Stress and burnout among Finnish dairy farmers. J Agromedicine. 2016;21(3):259-268.

doi:10.1080/1059924X.2016.1178611

12. Hakanen J. Työn imun arviointimenetelmä (Utrecht Work Engagement Scale) [An Assessment Scale to Measure Work Engagement]. Helsinki, Finland: FIOH; 2009. In Finnish

13. IBM. The calculation of Bonferroni-adjusted p-values. Web site. http://www01.ibm.com/support/docview.wss?uid=swg21476685_Accessed December 28, 2017.

14. O'Rourke N, Hatcher L. A Step-by-Step Approach to Using SAS(R) for Factor Analysis and Structural Equation Modeling. $2^{\text {nd }}$ ed. Cary, NC: SAS Institute Inc; 2013.

15. Schafer JL. Analysis of Incomplete Multivariate Data. New York, NY: Chapman and Hall; 1997.

16. Kenward MG, Roger JH. An improved approximation to the precision of fixed effects from restricted maximum likelihood. Computational Statistics and Data Analysis 2009;53:2583-2595.

17. Nakagawa S, Schielzeth $\mathrm{H}$. A general and simple method for obtaining $R^{2}$ from generalized linear mixed-effects models. Methods Ecol Evol. 2013;4:133-142. doi:10.1111/j.2041-210x.2012.00261.x

18. Barton K. MuMIn: multi-model inference. R package version 1.40.0. Web site. https://CRAN.R-project.org/package=MuMIn Accessed December 30, 2017.

19. Tike. Yearbook of Farm Statistics 2011. Helsinki, Finland: Edita Prima Ltd; 2011. 
20. ProAgria. Navettatyypit tuotosseurantakarjoissa [Cattle Barn Types among the Milk Production Record Farms]. Helsinki, Finland: Ruokatieto; 2011. In Finnish

21. Griffin MA, Clarke S. Stress and well-being at work. In: Zadeck S, ed. APA Handbook of Industrial \& Organizational Psychology. Vol 3. Washington, DC: American Psychological Association; 2010:359-397. doi:10.1037/12171-010

22. Sonnentag S, Frese M. Stress in organizations. In: Borman WC, Ilgen DR, Klimoski RJ, eds. Comprehensive Handbook of Psychology. Vol. 12. New York, NY: Wiley; 2003:453-491.

23. Väre M. Finnish farm. In: Niemi J, Ahlstedt J eds. Finnish Agriculture and Rural Industries 2015. Helsinki: Natural Resources Institute Finland, Luke; 2015:13-17.

24. Pråhl-Ollila M. Nuoret viljelijät maatalouden murroksessa [Young Farmers and Restructuring of Agriculture]. Espoo, Finland: Mela; 1995. In Finnish

25. Keating NC. Reducing stress of farm men and women. Fam Relat. 1987; 36(4):358-363. doi: $10.2307 / 584482$

26. Kulmala A, Leskinen J, Taattola K, Klen T. Stressi, kriisit ja niiden hallintaodotukset lypsykarjatiloilla [The Management of Stress and Crisis on Dairy Farms]. Kuopio, Finland: Kuopion aluetyöterveyslaitos; 1998. In Finnish

27. Melberg K. Farming, stress and psychological well-being: the case of Norwegian farm spouses. Sociol Ruralis. 2003;43(1):56-76. doi:10.1111/1467-9523.00229

28. Parry J, Barnes H, Lindsey R, Taylor R. Farmers, Farm Workers and Work-Related Stress. Suffolk, UK: HSE Books; 2005.

29. Kyyrä J, Mattila P, Väre M. Maatalouslaskenta 2010 [Agricultural Census 2010]. Helsinki, Finland: Information Centre of the Ministry of Agriculture and Forestry; 2011. In Finnish

30. Von Schlippe A, Frank H. The theory of social systems as a framework for understanding family businesses. Fam Relat. 2013;62(3):384-398. doi:

10.1111/fare. 12010

31. Vainio A, Kauppinen T, Valros A, Raussi S, Vesala KM. Väline vai itseisarvo? Tuotantoeläinten hyvinvoinnin edistäminen tuottajien asenteiden kohteena [A means to an end, or a value in itself? - Producer attitudes towards improving animal welfare]. Seinäjoki, Finland: University of Helsinki, Ruralia Institute; 2007. In Finnish

32. Kallioniemi MK, Kymäläinen H-R. Women on Finnish dairy farms: hard work in the midst of traditions and changes. Rural Soc. 2012; 22(1):78-89.

doi:10.5172/rsj.2012.22.1.78 
33. McGowan C. Women in agriculture. In: Pannell D, Vanclay F. eds. Changing Land Management: Adoption of New Practices by Rural Landholders. Melbourne, Australia: CSIRO Publishing; 2011:141-152.

34. Alston M. Who is down on the farm? Social aspects of Australian agriculture in the 21st century. Agric Hum Values. 2004;21(1):37-46.

doi:10.1023/B:AHUM.0000014019.84085.59

35. Niskanen K. Gender economics in action: rural women's economic citizenship in Finland during the twentieth century. $J$ Womens Hist. 2001;13(2):132-152. doi:

10.1353/jowh.2001.0054

36. Tike. Yearbook of Farm Statistics 2014. Helsinki, Finland: Juvenes Print Ltd; 2014.

37. Hakanen J. Työuupumuksesta työn imuun: Työhyvinvointitutkimuksen ytimessä ja reunaalueilla [From burnout to engagement: In the core and on the fringes of work-related well-being research. Dissertation]. Helsinki, Finland: FIOH; 2005. In Finnish

38. Mäkikangas A, Feldt T, Kinnunen U. Positiivisen psykologian näkökulma työhyvinvointiin [The view of positive psychology about well-being at work]. In: Kinnunen U, Feldt T, Mauno S eds. Työ leipälajina. Työhyvinvoinnin psykologiset perusteet [Well-being at work. The principles of psychology]. Keuruu, Finland: PSkustannus; 2005:56-74. In Finnish

39. Kinnunen U, Hätinen M. Työuupumus ja jaksaminen työelämässä [Burn out and coping in working life]. In: Kinnunen U, Feldt T, Mauno S eds. Työ leipälajina.

Työhyvinvoinnin psykologiset perusteet [Well-being at work. The principles of psychology]. Keuruu, Finland: PS-kustannus; 2005:38-55. In Finnish

40. Darnhofer I, Bellon S, Dedieu B, Milestad R. Adaptiveness to enhance the sustainability of farming systems. A review. Agron Sustain Dev. 2010;30(3):545-555.

doi:10.1051/agro/ 2009053

41. Pearlin LI, Schooler C. The structure of coping. J Health Soc Behav. 1978;19:2-21. doi: $10.2307 / 2136319$

42. Niemi J. First 15 years in the EU for Finnish agriculture and food economy. In: Niemi J, Ahlstedt J, eds. Finnish Agriculture and Rural Industries. Jokioinen, Finland: MTT Agrifood Research Finland; 2010:5-9.

43. Rautelin M. Valonpilkahdus viljelijän ahdinkoon [A flicker of light to difficulties among farmers]. Tieto \& trendit 2016;2. (June 28, 2016) In Finnish

44. Niemi J. Livestock production. In: Niemi J, Ahlstedt J eds. Finnish Agriculture and Rural Industries 2015. Helsinki, Finland: Natural Resources Institute Finland (Luke); 2015:34-38. 
45. Rantala O, Tauriainen J. Development of results and profitability in agriculture and horticulture. In: Niemi J, Ahlstedt J, eds. Finnish Agriculture and Rural Industries 2015. Helsinki, Finland: Natural Resources Institute Finland (Luke); 2015:60-65.

46. Ådahl S. Good Lives, Hidden Miseries. An Ethnography of Uncertainty in a Finnish Village [Dissertation]. Helsinki, Finland: University of Helsinki; 2007.

47. Perkiö-Mäkelä M, Hirvonen M, Kinnunen B, et al. Työterveys ja maatalous Suomessa [Occupational Health and Agriculture in Finland]. Helsinki, Finland: FIOH; 2016. In Finnish

48. Andrade SB. Transition and adaptation: an analysis of adaptation strategies amongst Danish farm families from 1980-2008. Sociol Ruralis. 2016;56(3):371-390. doi: $10.1111 /$ soru. 12091

49. Taleb NN. Antifragile. Things that Gain from Disorder. New York, NY: A Peguin Random House Publishing; 2012.

50. Mann CJ. Observational research methods. Research design II: cohort, cross sectional, and case-control studies. Emerg Med J. 2003;20(1):54-60. doi:10.1136/emj.20.1.54

51. Hulley SB, Cummings SR, Browner WS, Grady DG, Newman TB. Designing Clinical Research. Philadelphia, USA: Wolter Cluwer Health, Lippincott Williams \& Wilkins; 2007.

52. Altmets K, Puur A, Uusküla A, Saaval A, Sakkeus L, Katus K. Self-reported activity limitations among the population aged 20-79 in Estonia: a cross-sectional study. Eur J Public Health. 2011;21(1):49-55. doi:10.1093/eurpub/ckp239

53. Kallio V. Suomalaisen viljelijäväestön henkinen ilmapiiri [The Mental Atmosphere among the Finnish Farming Population]. Mikkeli, Finland: University of Helsinki:1997. In Finnish

54. Pråhl-Ollila M. Selviytyjiä, epätietoisia ja putoajia. Nuoren viljelijäväestön erilaistuminen [Survivors, Uncertain and Dropped out. Differentiation of Young Farmer Population]. Espoo, Finland: Mela; 1997. In Finnish

55. Stain HJ, Kelly B, Lewin TJ, Higginbotham N, Beard JR, Hourihan F. Social networks and mental health among a farming population. Soc Psychiatry Psychiatr Epidemiol. 2008;43:843-849. doi:10.1007/s00127-008-0374-5

56. Kallioniemi MK, Simola A, Kinnunen B, Kymäläinen H-R. Stress in farm entrepreneurs. In: Langan-Fox J, Cooper CL, eds. Handbook of Stress in the Occupations. Cheltenham, UK: Edward Elgar; 2011:385-406. doi:10.4337/9780857931153

57. Deary IJ, Willock J, McGregor M. Stress in farming. Stress Med. 1997;13(2):131-136. doi:10.1002/(SICI)1099-1700(199704)13:2<131::AID-SMI727>3.0.CO;2-T 
58. Firth HM, Williams SM, Herbison GP, McGee RO. Stress in New Zealand farmers. Stress Health. 2007;23(1):51-58. doi:10.1002/smi.1119

59. Simkin S, Hawton K, Fagg J, Malmberg A. Stress in farmers: a survey of farmers in England and Wales. Occup Environ Med. 1998;55(11):729-734. doi:10.1136/oem.55.11.729

60. Booth NJ, Lloyd K. Stress in farmers. Int J Soc Psychiatry. 2000;46(1):67-73. doi:10.1177/002076400004600108

61. Glasscock DJ, Rasmussen K, Carstensen O, Hansen ON. Psychosocial factors and safety behaviour as predictors of accidental work injuries in farming. Work Stress.

2006;20(2):173-189. doi:10.1080/02678370600879724

62. Anxiety and Depression Association of America. Stress. Web site. http://www.adaa.org/understanding-anxiety/related-illnesses/stress Accessed September 4, 2017 